Artigo Original

\title{
Gasification system coupled to fixed bed column aiming adsorption of $\mathrm{H}_{2} \mathrm{~S}$ from biomass
}

\author{
Sibéria Caroline Gomes de Moraes'; Adalberto Freire do Nascimento Júnior"l; \\ Shirlene Tamires Oliveira dos Santos"II; Ana Maria Ribeiro Bastos da Silvalv; \\ Sérgio Peres Ramos da Silvav; Valdinete Lins da Silvav"; Celmy Mª B. de Menezes Barbosav"I
}

\section{Abstract}

An overview of the characterization of biomass sugarcane bagasse, peanut shell and black grape peel for application of biofuels, based on laboratory tests. Initially a general explanation of the development of gasification for the production of synthetic natural gas from alternative sources, such as biomass, which can be converted from solid to gaseous fuel, passing through a process of purification through adsorption in a fixed bed system. The adsorbent was evaluated through BET, BJH, pH, humidity and ignition loss analyzes. The results of the combined gasification capacity of the adsorption column for the cleaning of the produced fuel gas and adsorption of the $\mathrm{H}_{2} \mathrm{~S}$ were analyzed. The biomass results were discussed in terms of the energy potential as fuel based on the principal component analysis (PCA).

Keywords: Biomass; Fuel gas; Energy

' Departament of Chemical Engineering. Federal University of Pernambuco. Avenida Professor Moraes Rego, 1235, Cidade Universitária 50670-901 Recife, PE - Brazil.msibria@yahoo.com

"Departament of Mechanical Engineering. Polytechnic School of Pernambuco. University of Pernambuco. Rua Benfica, 455, térreo bloco C; Madalena 50720001 - Recife, PE - Brazil. adalbertofreire2@gmail.com

II' Departament of Mechanical Engineering. Polytechnic School of Pernambuco. University of Pernambuco. Rua Benfica, 455, térreo bloco C; Madalena 50720001 - Recife, PE - Brazil. shirlene.tamires@hotmail.com

Iv Departament of Chemical Engineering. Federal University of Pernambuco. Avenida Professor Moraes Rego, 1235, Cidade Universitária $50670-901$ Recife, PE - Brazil.amrbsilva@gmail.com

${ }^{\vee}$ Departament of Mechanical Engineering. Polytechnic School of Pernambuco. University of Pernambuco. Rua Benfica, 455, térreo bloco C; Madalena 50720001 - Recife, PE - Brazil. sergperes@gmail.com

Vi Departament of Chemical Engineering. Federal University of Pernambuco. Avenida Professor Moraes Rego, 1235, Cidade Universitária $50670-901$ - Recife, PE - Brazil. leaq_val@yahoo.com.br

VII Departament of Chemical Engineering. Federal University of Pernambuco. Avenida Professor Moraes Rego, 1235, Cidade Universitária $50670-901$ Recife, PE - Brazil.celmy@ufpe.br 


\section{Introduction}

Due to environmental issues, regulatory restrictions on greenhouse gas pollution have increased, leading to an improvement in the quality of fuels worldwide, large investments in synthetic liquid fuel technology have attracted the attention of companies in the energy sector [1]. Mainly in the conversion of synthetic natural gas ( $\mathrm{SNG})$, obtained from natural gas (NG), known as GTL (gas to liquid) technology. However, it is very likely that natural gas reserves are increasingly limited [2], therefore, other technologies for the production of SNG from alternative sources, such as biomass (liquid biomass, BTL), reaching high levels of purity and high energy efficiency [3] appear as an option for fuel gas. Biomass is an abundant and renewable energy, it is the fourth largest source of energy in the world, its conversion is rich in synthesis gas, becoming a precursor of great interest in relation to other sources [4]. Compared with fossil fuels do not emit greenhouse gases [5]. According to Bocci et al. [6] the efficiency of the biomass energy conversion process will depend on several factors, among them, its physicochemical composition.

To determine the potential of a biomass as a fuel and to be able to evaluate how best to use it in a more advanced thermodynamic project, it is necessary to first know its fundamental physicochemical characteristics, since it is these properties that determine both the choice of the process [7; 8]. The main properties of interest for the study of biomass conversion processes are: calorific value; moisture content; chemical composition (immediate and elementary); granulometry; bulk density and chemical composition of the fibers (lignin, cellulose and hemicellulose) and thermal analysis.

Therefore, due to this renewable resource, the production of synthesis gas (SG) for GTL technology is being studied, giving rise to new types of plants for fuel generation. The SG is also important in industrial processes involving combustion, providing faster and cleaner burning in relation to solid fuels, the same is produced from gasification processes, in which the organic matter (biomass) is transformed into gas by burning, in a condition of air shortage in relation to the stoichiometric firing. Gasification involves a large number of parallel reactions, most of which are endothermic and must be maintained by the partial combustion of the generated gas or by external heat supply. The gasification process is divided into: drying, pyrolysis, oxidation and reduction [9].

The SG from the gasifier needs to be purified when fuel is produced, usually this requires desulphurisation (often down to ppb level) due to sulfur compounds [10]. Purification of the biomass gasification gas before the catalytic unit step is a promising method for obtaining clean fuels and has become a challenge for the non-deactivation of the Fischer-Tropsch catalyst since the biomass gasification gas contains remarkable amounts of $\mathrm{H}_{2} \mathrm{~S}$ (in the range of 100 to $500 \mathrm{ppm}$ ) depending on the feedstock [11]. Therefore, the need for purification of the synthesis gas and removal of the most recalcitrant contaminant, the sulfur, in the form of $\mathrm{H}_{2} \mathrm{~S}$, requires alternatives of cleaning technologies, among them, the adsorption, an effective process for the removal of polluting constituents.

The adsorption is a mass transfer operation, which studies the ability of certain solids to concentrate certain substances in liquid or gaseous fluids, allowing separation of the components of these fluids [12]. One of the frequently studied adsorbent materials is ash, residues from the burning of sugarcane bagasse, a complex material of heterogeneous chemical composition and morphology [13].

According to Oliveira [14], ash is a complex biogenic organic-inorganic solid product generated by anthropogenic (technological) or natural processes, its use as adsorbent is also directed to remove raw material or petrochemicals from wastewater; to remove odor emitting toxic substances from residual aqueous solutions; to remove certain dyes in water from textile factories, and in the disposal of heavy metals from industrial effluents.

Ashes from biomasses have considerable ion exchange capacity because they contain oxygen containing functional groups, such as silanol, hydroxyl, carboxylic, phenolic and others that can adsorb the metals. On the other hand, alkaline and alkaline earth oxides, hydroxides and carbonates are predominant among ash components and this explains their alkalinity and has excellent ability to capture sulfur and other compounds [15].

Hachimi et al. [16] studied that in the biomass burning processes, gasification, in which there is production of $\mathrm{H}_{2} \mathrm{~S}$, a compound that attacks the active sites of the catalysts, required that the synthesis gas needed to reach ppb levels to produce fuel. It can be achieved by the reaction of sulphidation with a metal oxide (MOx): $\mathrm{MyOx}+\mathrm{xH}_{2} \mathrm{~S} \rightarrow \mathrm{MySx}+\mathrm{xH}_{2} \mathrm{O}$; after this reaction, the sulfur material can be regenerated under an oxidizing atmosphere and by thermal decomposition of the sulfates: $\mathrm{MySx}+(3 / 2) \mathrm{xO}_{2} \rightarrow \mathrm{MyOx}+\mathrm{xSO}_{2}$. As an example of the work of Hachimi et al. [16], they studied the copper oxides and the mixed copper oxides, where they presented the best results for the desulphurisation process.

Chytil et al. [17] evaluated the removal of $\mathrm{H}_{2} \mathrm{~S}$, produced from biomass gasification, and verified in its adsorption systems the advantages and disadvantages, where it was observed that adsorbents based on manganese, copper and zinc oxide presented good yield of their capacity of adsorption, being its advantage; however, as a disadvantage, these oxides have a long period of adsorption time tend to deactivate by sintering (a process that creates a change in the microscopic structure of the base element).

\section{Materials and methods}

The methodology for the development of this research was divided in three stages: collection, treatment and physical-chemical characterization of the biomass for the production of the combustible gas and analysis of the adsorbent.

\subsection{Material collection}

For the accomplishment of this work, the bark of the black grapes skin (BGS) was used, its origin was of the Municipality of Petrolina-PE, the peanut shells (PS) from the municipality of Santa Maria da Boa Vista-PE and sugarcane bagasse (SCB) from a commercial establishment in Pernambuco (CEASA-PE). The ash from sugarcane bagasse was collected from the J.B Plant, located in the 
city of Vitoria de Santo Antão-PE. All collected in the period from June 1 to June 30, 2016.

\subsection{Treatment of the material}

After collection, peanut shell (PS), black grapes skin (BGS) and sugarcane bagasse (SCB) samples were characterized for the laboratory tests, being developed in the Laboratory of Fuel of the University of Pernambuco. In the characterization laboratory, each biomass underwent a previous treatment, which consisted of the spraying, homogenization and drying stages, in accordance with ABNT NBR 6.923/1981: Charcoal - Sampling and sample preparation.

In the preparation of the adsorbent, this step was developed in the Laboratory of Environmental and Quality Engineering (LEQE) at UFPE.

- Pure ash: The ash was worked in its in natura form in the amount of $20 \mathrm{~g}$, the only preparations in this stage were the use of a sieve with MESH 65 to leave the same homogeneous and remove possible contaminations such as sand and small pieces of wood, of this the ash was washed with $50 \mathrm{~mL}$ of water, dried in an oven at $273 \mathrm{~K}$, cooled and stored.

\subsection{Analyzes made on materials}

(a) Biomass: sugarcane bagasse, black grapes skin and peanut shells.

The fundamental characteristics that were determined for the biomass are written as follows. Each laboratory test was repeated 3 times, to obtain a better result and decrease of analytical error [18].

\subsubsection{Particle size analysis}

An analysis to determine the particle size characteristics of the biomass types used was carried out using standard sieves. This characterisation method consists on the mechanical separation of different fractions of the material by using a set of sieves with determined mesh size, placed gradually on top of one-another, with the larger sieve opening being placed on top, in accordance to the ABN NBR NM 248/2003 Norm: Aggregates - determination of particle size composition. Particles with a bigger characteristic grain size than the corresponding mesh were retained in the respective sieve. In the same way, particles with a characteristic dimension smaller than the mesh size pass through the corresponding sieve. $(10.00 \pm 0.01) \mathrm{g}$ of the biomass types were sieved in a mechanic sieve shaker, with the following mesh sizes being observed: sugarcane bagasse, MESH 28-35; grape skin and peanut shell, MESH 20-28.

The mass of the different grain size fractions were then calculated having individually determined the mass contained in each mesh and dividing the result by the initial value sieved, estimated according to Equation 1 described by Lora et al. [19]:

Where is the standard mesh size of the respective sieve particles pass through and the mesh size of the sieve particles were retained.
$\mathrm{D}_{\mathrm{c}}=\left[\frac{\left(\mathrm{X}_{\mathrm{p}}^{2}+\mathrm{X}_{\mathrm{r}}^{2}\right) *\left(\mathrm{X}_{\mathrm{p}}+\mathrm{X}_{\mathrm{r}}\right)}{4}\right]^{1 / 3}$

\subsubsection{Moisture content on dry basis}

In order to determine the moisture content, the ABNT NBR 14.929/2003: Wood - Determining Wood Chip Moisture Content - oven drying method. Samples containing $(3.00 \pm 0.01) \mathrm{g}$ of the raw materials studied were conditioned in a recipient of mass known, weighed and taken to be dried in the oven at $(105 \pm 2)^{\circ} \mathrm{C}$. Throughout the drying process, the samples were weighed every 2 hours, until having presented a variation lower or equal to $0.5 \%$ of the last mass measured, which would be considered as the dry mass. After each set period of time in the oven, the samples were kept in a desiccator containing active silica, as a way of ensuring adequate cooling. The dry basis moisture content was subsequently calculated according to Equation 2.

$\% \mathrm{~W}=\frac{[\mathrm{A}-(\mathrm{B}-\mathrm{C})]}{\mathrm{B}-\mathrm{C}} * 100$

With A being the initial mass of the sample, B the mass of the system formed by the recipient and by the dry sample, and $C$ the mass of the empty recipient and dried in the oven at $(105 \pm 2)^{\circ} \mathrm{C}$.

Bulk Density $(B D)=\left(\frac{m_{b}-m_{v}}{V i}\right)$

\subsubsection{Calorific Value}

The calorific value was determined according to the same ABN NBR 6.992/81 norm: Charcoal - Determining Calorific Value - Test method using a bomb calorimeter. The trials were carried out using a Digital Calorimeter consisting of an adiabatic oxygen bomb, a distilled water unit and a decomposition vessel.

With this method, the condensed and previously weighed biomass $(0.3 \mathrm{~g}-0.5 \mathrm{~g}$ approximately) was conditioned inside the crucible (combustion chamber), subsequently being placed inside the decomposition vessel. When correctly sealed, the vessel was placed inside the adiabatic oxygen bomb.

Throughout the trial, the adiabatic bomb was filled with a known mass of distilled water from the water unit, with oxygen being subsequently injected inside the decomposition vessel at a pressure of 30 bar. When the temperature controlled jacket matched the temperature of the decomposition vessel to the distilled water temperature, the combustion of biomass in the combustion chamber took place. Due to the energy released during the combustion process, the temperature of the water inside the adiabatic bomb was increased to its maximum, and registered accordingly. 
After having carried out the trial, the decomposition vessel was removed from the equipment and the pressure released so that the lid could be removed. The heat of combustion, or the higher calorific value of the sample,

$$
\mathrm{HCV}=\frac{\mathrm{m}_{\text {water }} \cdot \mathrm{c}_{\mathrm{p}} \cdot\left(\mathrm{T}_{\mathrm{f}}-\mathrm{T}_{\mathrm{i}}\right)}{\mathrm{m}_{\text {sample }}}
$$

was calculated according to Equation 4:

With Tf and Ti being the initial and final temperatures registered, and $\mathrm{Cp}$ the calorific capacity of water at a constant pressure.

For the lower calorific value, an analysis of the water of combustion present in the decomposition vessel was carried out after the process, according to the procedure indicated by the manufacturer. For this procedure, the decomposition vessel was rinsed with $50 \mathrm{~mL}$ of distilled water and the mixture collected with the use of an Erlenmeyer. An orange-coloured methyl indicator was then added to the mixture. The mixture was subsequently titrated with a solution of sodium hydroxide at $0.1 \mathrm{~N}$ factored until the change in colour, with a $20 \mathrm{~mL}$ solution of $0.05 \mathrm{~N}$ sodium carbonate being added afterwards. The quantities of $\mathrm{NaOH}$ and $\mathrm{HCl}$ used were then noted and multiplied by their respective factors. These data were inserted in the in Calorimeter software, which automatically calculated the LCV.

\subsubsection{Immediate chemical composition and thermal analysis}

The contents of volatile matter, fixed carbon and ashes of biomass were obtained according to the ABNT NBR 8.112/86 norms: Charcoal - Immediate Analysis - Test Method using a thermogravimetric scale. For obtaining the data for volatile matter and fixed carbon, a constant heat rate of $10^{\circ} \mathrm{C} . \mathrm{min}-1$ was imposed, from a room temperature to a temperature of $900^{\circ} \mathrm{C}$, using nitrogen as carrier gas, creating a non-reactive atmosphere in the oven. After reaching $900^{\circ} \mathrm{C}$, oxygen gas began being injected in the oven, provoking a reaction between the matter's fixed carbon and $\mathrm{O}_{2}$ from the environment, forming carbon dioxide, with only ashes remaining in the composition.

\subsubsection{Elementary Chemical Composition}

The elementary analysis was carried out using a Vario Macro Equipment, according to the ASTM D5373/2008 norms: Standard Test Methods for Instrumental Determination of Carbon, Hydrogen, and Nitrogen in Laboratory Samples of Coal and the ASTM D4208/2007 norm: Standard Test Method for Total Chlorine in Coal by the Oxygen Bomb Combustion/Ion Selective Electrode Method.

\subsubsection{Chemical Composition of Fibres}

The composition of cell walls can vary significantly from one biomass species to another. Therefore, an analysis that can provide the exact chemical composition of the raw materials used in the gasification experiments is considered necessary. This analysis is known as Van Söest and Robertson Analysis [20], and is divided into three steps:

Neutral Detergent Fibre (NDF): provides the quantity of fibres in the biomass type (cellulose, hemicellulose and lignin, altogether), as well as the percentage of insoluble ash;

Acid Detergent Fibre (ADF): measures the amount of cellulose and lignin, altogether;

Klason Lignin: establishes the amount of lignin in the sample.

\subsubsection{Analysis of Neutral Detergent Fibre}

The NDF method is used for measuring the percentage of cellular components and cell walls. The analysis is capable of removing all cellular components in the dry sample, leaving only the components from the cell walls, i.e. cellulose, hemicellulose, lignin and insoluble ash.

The solution used in this methodology was prepared with $30 \mathrm{~g}$ of sodium lauryl sulfate, $18.61 \mathrm{~g}$ of ethylene diamine tetra acetate (EDTA) disodium, $4.61 \mathrm{~g}$ of disodium phosphate, $6.81 \mathrm{~g}$ of sodium borate and $10 \mathrm{~mL}$ of triethylene glycol, per litre of distilled water. The $\mathrm{pH}$ of the NDF solution had to be kept between 6.9 and 7.1. If necessary, the $\mathrm{pH}$ could have been corrected with a solution of $10 \% \mathrm{HCl}$ or $10 \% \mathrm{NaOH}$.

The analysis for the NDF followed the subsequent procedure: one gram of previously milled and dried sample and ground through a $1-\mathrm{mm}$ sieve was placed in a $600 \mathrm{~mL}$ glass beaker. Subsequently, $100 \mathrm{~mL}$ of the neutral detergent solution, together with antifoam drops (amyl alcohol), were added to the beaker containing the sample. The sample was then digested by refluxing for 1 hour from boiling point, in order to dissolve all cellular constituents.

After digestion, the boiled solution was filtered with vacuum in the crucible with a previously weighed porous plate and previously collected fibres. The residues from the beaker were removed by adding hot water (minimum of $80^{\circ} \mathrm{C}$ ); with the rinsing with hot water being repeated threefold. When all residues were transferred from the beaker to the porous crucible, the sample was boiled and then rinsed twice with acetone. The crucible with porous plate was subsequently taken to the oven, where it remained being heated for 4 to 6 hours, at a temperature of $105^{\circ} \mathrm{C}$. The cellular content was therefore calculated from Equation 5:

$$
\% \mathrm{NDF}=\left(\frac{\mathrm{A}-\mathrm{B}}{\mathrm{C}}\right) * 100
$$

With A being the mass of the crucible with porous plates with digested fibres (after being dried in the oven), $B$ the mass of the empty crucible and $C$ the initial mass of the sample. Since all the material to be weighed remained in the oven before being measured, the result 
was given on a dry basis.

\subsubsection{Analysis of Acid Detergent Fibre}

The analysis of ADF removes the lignocellulose and silica (insoluble ash) from the raw material. The difference between the masses obtained in the analysis of neutral detergent fibre and acid detergent fibre therefore provides an estimation of the amount of hemicellulose on the cell walls. Besides, the analysis of ADF is an initial step for determining lignin content on the cell walls.

The solution used in the analysis methodology consisted of $30 \mathrm{~mL}$ of sulfuric acid for every $500 \mathrm{~mL}$ of distilled water, with sample being simmered in this solution for one hour. After being cooled, $1 \mathrm{~L}$ of distilled water was added. Subsequently, 20g of Cetyltrimethylammonium bromide (CTAB) was added for every $1000 \mathrm{~mL}$ of $\mathrm{H}_{2} \mathrm{SO}_{4} /$ distilled water solution, being stirred until its complete dissolution.

The experimental procedure is similar to the analysis of neutral detergent fibre. The lignocellulose content is calculated by subtracting the mass of the crucible with porous plates with the digested fibres inside (after being dried in the oven) from the mass of the empty crucible, with the result being divided by the initial sample mass. As all the material to be weighed remained inside the oven before being measured, the result was given on a dry basis.

\subsubsection{Klason Lignin Analysis}

The methodology for determining the amount of Klason lignin uses the fibre resulting from the analysis of acid detergent as raw material. The experimental procedure is based on the fact that cellulose is dissolved by sulfuric acid at $72 \%$, leaving only lignin and insoluble ash as residues.

$300 \mathrm{mg}$ of extractive-free material previously dried was initially added to a mortar and pestle set, with the subsequent addition of $3 \mathrm{~mL}$ of sulfuric acid at $72 \%$. Afterwards, the mixture of fibres/acid was ground for 1 hour, at room temperature $\left(25^{\circ} \mathrm{C}\right)$. The material was then transferred to a glass beaker, diluted in $84 \mathrm{~mL}$ of distilled water and boiled by refluxing for 4 hours.

After reflux, the mixture of fibres/solution with sulfuric acid in a glass crucible with porous plates previously weighed was filtered with vacuum, with the residual material (Klason lignin) being rinsed with hot water. The crucible remained in the oven at $105^{\circ} \mathrm{C}$ for 4 to 6 hours. The Klason lignin content is therefore determined by dividing the mass of lignin obtained by the initial mass of fibres, with the result being given in percentage, according to Equation 6.

$\%$ Lignin $=\left(\frac{\text { masslignin }}{\text { massbiomass }}\right) * 100$

For determining Cellulose and Hemicellulose, the calculation procedure is described by Equations 7 and
8 below:

$\%$ Hemicellulose $=[\mathrm{A}-\mathrm{B}]$

$\%$ Cellulose $=[\mathrm{B}-\mathrm{Z}-\mathrm{C}]$

With: $A=N D F ; B=A D F ; Z=$ lignin e $C=$ ash content

\section{(b) Statistical Analysis}

The basic descriptive and multivariate analysis of the principal components (PCA) was carried out using the StatisticaStatSoft ${ }^{\circledR}$ version 7 Software.

\section{(c) Ash from sugarcane bagasse}

The ashes present a variety of characteristics that can be provoked by many factors, among them, pressure and temperature, since they are natural industrial residues and obtained from the burning of the bagasse of sugarcane.

\subsubsection{BET method, isotherms and BJH}

This method makes it possible to determine the textural characteristics of an adsorbent material, such as pore diameter and surface area. The determination of these characteristics is very important in the characterization of an adsorbent, since they are very related to the mass transfer processes. The general objective is to measure the amount of a gas adsorbed on the surface as a function of the pressure of this gas. The determination of the ash surface area was determined by the adsorption of $\mathrm{N}_{2}$ at $77+/-5 \mathrm{~K}$ in a BELSORPT-MINI equipment. To remove the moisture from the sample surface a $333 \mathrm{~K}$ pre-treatment under vacuum (DEGASS) was performed for 3 hours and, using the $\mathrm{N}_{2}$ method and using the Brunauer-Emmett-Teller Equation (BET), the values were obtained. The pore size distribution was estimated by applying the Barrett-Joyner-Halenda method $(\mathrm{BJH})$ and using the desorption data of the isothermal curve and analyzing the adsorption isotherms [21].

\subsubsection{1 $\mathrm{pH}$}

The analysis was performed by placing $2 \mathrm{~g}$ of the sample in contact with deionized water in a $250 \mathrm{~mL}$ erlenmeyer flask, stirred for $24 \mathrm{~h}$ on a magnetic stirrer at $120 \mathrm{rpm}$, after filtration, the $\mathrm{pH}$ of the solutions was measured with a $\mathrm{pH}$ meter [22; 23].

\subsubsection{Moisture}

The determination was carried out with $0.2 \mathrm{~g}$ of the sample, the moisture content was calculated according to the loss of mass of the sample subjected to a heating at $378 \mathrm{~K}$, for 24 hours in a furnace and expressed in percentage [23].

\subsubsection{Loss of ignition}

The fire loss or ignition loss, which means different amounts of carbon (carbon) is expressed as a percentage by weight of dry mass. The process occurred when $2 \mathrm{~g}$ of 
the sample reached a constant mass of $0.5 \%$, after drying in an oven at $100^{\circ} \mathrm{C}$ for 1 hour, corresponding to the dry mass; after that step the sample was brought to muffle at $550+/-25^{\circ} \mathrm{C}$ for 1 hour, corresponding to the inflamed dry mass. The calculation follows Equation 9 and expressed in percentage according to the author TC WI [24]:

$\% \mathrm{Mv}=\left(\frac{\mathrm{mb}-\mathrm{mc}}{\mathrm{mb}-\mathrm{ma}}\right) * 100$

Being: $\mathrm{Mv}=$ loss by ignition; $\mathrm{ma}=$ mass of the empty crucible (g); $\mathrm{mb}=$ mass of the crucible containing the dry mass $(\mathrm{g}) ; \mathrm{mc}=$ mass of the crucible contains the inflamed dry mass (g).

\section{(d) Gasification and Fixed Bed Column (reactive tests)}

For the gasification tests, a laboratory mini-gasifier, an equipment that operated in batch mode, was used. The equipment consists of a horizontally arranged furnace (main piping), connected to a set of secondary piping and valves. The oven, constructed of seamless Schedule 80 steel (to avoid stress concentrating areas), is $760 \mathrm{~mm}$ long; 50.8 $\mathrm{mm}$ outside diameter; and, $38.1 \mathrm{~mm}$ internal diameter. Welded throughout the furnace, there are 3 branches of Schedule 40 steel, $300 \mathrm{~mm}$ in length; $19.05 \mathrm{~mm}$ outside diameter; and $12.7 \mathrm{~mm}$ internal diameter. The branches are separated by $150 \mathrm{~mm}$ center to center. A K-type thermocouple is connected to the free end of each branch so that the tip of its stem is located exactly in the center of the main tubing in addition to the pressure gauge. The temperatures in the furnace and the internal pressure of the gasifier were acquired by two dataloggers myPCLab, manufactured by NOVUS Electronic Products, which are connected to a computer via USB cables.

Coupled to the gasifier was a fixed bed adsorption column, with the following specifications: outer diameter $3.15 \mathrm{~cm}$ and internal diameter $2.86 \mathrm{~cm}$, total height of glass column $18 \mathrm{~cm}$, column height above throttling 12 $\mathrm{cm}$ and column height below the bottleneck $6 \mathrm{~cm}$. The materials added in the fixed bed column for sustainability and non-dragging of the adsorbent when the gas is traversing the column were glass wool $(1 \mathrm{~cm}$ high) and glass beads $(1 \mathrm{~cm}$ high). In the development of the work the internal pressure of the cylinder was 1500 to $2000 \mathrm{psi}$, the working pressure was $10 \mathrm{psi}(\sim 0.7 \mathrm{bar})$, the upflow measured in the bolhometer was $25 \mathrm{~mL} \cdot \mathrm{min}-1$ and the ambient temperature of $25^{\circ} \mathrm{C} \pm 5{ }^{\circ} \mathrm{C}$.

\section{e) Gas Chromatography}

To determine the $\mathrm{H}_{2} \mathrm{~S}$ study, a quantitative analysis was performed by a Thermo Scientific brand gas chromatograph. The chromatogram of the synthetic $\mathrm{H}_{2} \mathrm{~S}$ standard served as a basis for analyzing this gas when it was produced from biomass gasification, in Table 01 the methodology developed at the University of Pernambuco, at the Laboratory of Fuels and Energy, is described. The $\mathrm{H}_{2} \mathrm{~S}$ standard had an initial concentration of $500 \mathrm{ppm}$ and a volume of $1 \mathrm{~m}^{3}$, the chromatogram was performed by calculating the factor that is quantified by the chromatographer by area and concentration [25].

\section{Figure 01 - Shows the gasification process coupled to adsorption}

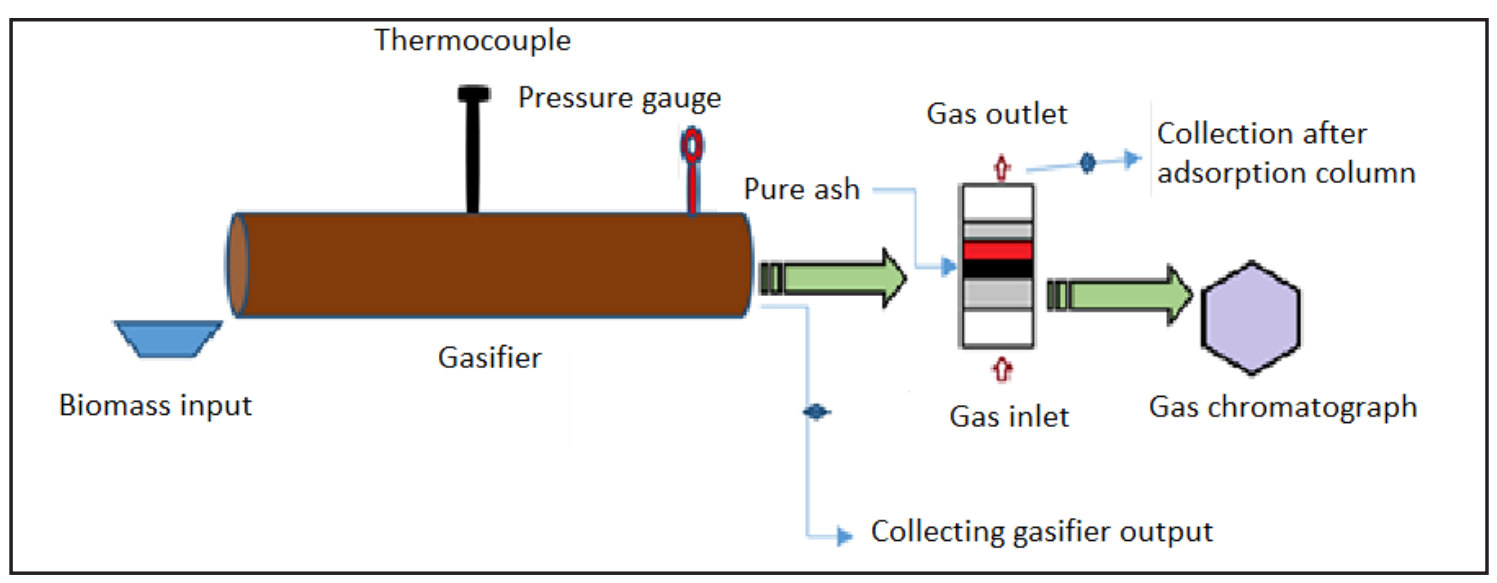

Procedure:

Step 1 - The three dried and crushed biomasses were weighed and the amount of each was: $8.39 \mathrm{~g}$ of the black grape skin; 8.09 $\mathrm{g}$ of peanut shells; and $8.21 \mathrm{~g}$ of the sugarcane bagasse. The biomasses, one at a time, were carbonated and the produced gas collected and injected into the gaseous chromatograph to determine the percentage of $\mathrm{H}_{2} \mathrm{~S}$ produced. Each experiment was performed in triplicate to calculate the arithmetic mean;

Step 2 - The gasifier was coupled in the adsorption column so that the gas produced was injected directly into the column for subsequent collection and reading in the chromatograph to know the concentration of $\mathrm{H}_{2} \mathrm{~S}$, noting that the same quantities of the three biomasses of the 1st stage were reweighed and, the adsorbent that was worked in this stage was the pure ash, because it is in natura and because it is a direct residue of a plant.

Note: The biomass gasification time was 3 minutes; the contact time between the gas produced and the adsorbent was 5 minutes; the working temperature range of the gasifier was between $700^{\circ} \mathrm{C}$ and $715^{\circ} \mathrm{C}$ and the working pressure was $3.5 \mathrm{kgf.cm}{ }^{-2}$. 
Table 01- Chromatographic Analysis of $\mathrm{H}_{2} \mathrm{~S}$

\begin{tabular}{|c|c|}
\hline Parameters & Valores \\
\hline Analysis time & 3 minutes \\
\hline Oven Temperature & Isothermal module $-120^{\circ} \mathrm{C}$ \\
\hline Gas flow rate & $1 \mathrm{ml}$ for $35 \mathrm{~mL}$ \\
\hline Injection mode & Split/Splitless \\
\hline Column & $\begin{array}{l}\text { RT-q bond plot; } 30 \mathrm{~m} \times 0,32 \mathrm{~mm} \times \\
1,0 \mu \mathrm{m} \text {; FPD flame photometer } \\
\text { with filter for sulfur }\end{array}$ \\
\hline Column Flow & 2,5 mL.min ${ }^{-1}$ (constant) \\
\hline Detector & $\begin{array}{l}\text { Base of the temperature } 200^{\circ} \mathrm{C} \text {; } \\
\text { Temperature FPD } 150^{\circ} \mathrm{C} \text {; Flow } \\
\text { do } \mathrm{H}_{2} 90 \mathrm{ml} \cdot \mathrm{min}^{-1} \text {; Airflow } 115 \\
\text { mL.min }{ }^{-1} \text {; Makup }\left(\mathrm{N}_{2}\right) 30 \mathrm{~mL} . \mathrm{min}^{-1} \text {; } \\
\text { Electronic attenuation } 100 \text { times } \\
\text { signal. }\end{array}$ \\
\hline
\end{tabular}

\section{Results and discussion}

The results are presented for the analyses run threefold, as exhibited in Table 02, referring to the biomass type Sugarcane Bagasse (SCB), Peanut Shell (PS) and Black Grapes Skin (BGS) dried and milled; in these results for a better understanding, a principal component analysis will be performed. As for the pure ash adsorbent, Table 03 presents the results of the BET analysis.

Gaseous adsorption is related to the pore surface area and BET analysis according to Pécora et al. [26] is the best evidence to determine adsorption performance, mesoporous and macroporous materials have a higher adsorption capacity when the adsorbate is a gas, because they have a high internal surface area. Characteristics of mesoporous materials conform to the shape of the Type IV isotherm according to IUPAC. The $\mathrm{pH}$ is related to the ions present on the surface of the material and the moisture is very related to the capacity of the adsorbent to retain water in its structure, as the loss of ignition its

Source: UPE - Fuel Lab, 2015

Table 02- Analyses of the characterisation of biomass types Sugarcane Bagasse (SCB), Peanut Shell (PS) and Black Grapes Skin (BGS

\begin{tabular}{|c|c|c|c|c|c|c|}
\hline \multirow{3}{*}{ Properties } & \multicolumn{6}{|c|}{ Biomass Types } \\
\hline & \multicolumn{2}{|c|}{ Sugarcane Bagasse (SCB) } & \multicolumn{2}{|c|}{ Peanut Shell (PS) } & \multicolumn{2}{|c|}{ Black Grapes Skin (BGS) } \\
\hline & Average & $\begin{array}{l}\text { Standard } \\
\text { Deviation }\end{array}$ & Average & $\begin{array}{l}\text { Standard } \\
\text { Deviation }\end{array}$ & Average & $\begin{array}{l}\text { Standard } \\
\text { Deviation }\end{array}$ \\
\hline (\%) Moisture & 12.80 & 0.43 & 9.12 & 1.16 & 82.83 & 1.26 \\
\hline (\%) Particle size analysis & 53.50 & 3.90 & 52.83 & 1.37 & 51.70 & 1.41 \\
\hline Bulk Density $\left(\mathrm{kg} \cdot \mathrm{m}^{-3}\right)$ & 267.00 & 2.65 & 356.67 & 15.01 & 823.00 & 4.00 \\
\hline Higher Calorific Value (kj.kg-1) & $14,617.67$ & 245.16 & $19,155.67$ & 153.08 & $18,496.00$ & 102.50 \\
\hline Lower Calorific Value $\left(\mathrm{kj.kg}^{-1}\right)$ & $14,403.67$ & 235.03 & $18,943.33$ & 169.06 & $18,288.00$ & 106.78 \\
\hline (\%) Volatiles (*) & 67.59 & 1.61 & 95.41 & 1.93 & 94.35 & 0.63 \\
\hline (\%) Fixed Carbon $\left({ }^{*}\right)$ & 1.52 & 0.35 & 0.40 & 0.13 & 0.74 & 0.12 \\
\hline (\%) Ashes (*) & 30.89 & 1.57 & 4.09 & 2.12 & 3.74 & 1.47 \\
\hline$\% C(* *)$ & 38.66 & 0.96 & 43.89 & 2.20 & 48.93 & 0.56 \\
\hline$\% \mathrm{~N}\left(*^{* *}\right)$ & 1.11 & 0.02 & 1.63 & 0.11 & 1.50 & 0.08 \\
\hline$\% \mathrm{H}\left({ }^{* *}\right)$ & 4.77 & 0.17 & 6.36 & 0.31 & 5.57 & 0.05 \\
\hline$\% \mathrm{~S}\left({ }^{* *}\right)$ & 0.82 & 0.07 & 0.95 & 0.03 & 0.74 & 0.03 \\
\hline$\% \bigcirc\left({ }^{* *}\right)$ & 52.25 & 1.67 & 47.31 & 2.58 & 42.60 & 0.44 \\
\hline (\%) Lignin (x) & 22.81 & 1.12 & 35.02 & 3.06 & 31.85 & 0.83 \\
\hline (\%) Hemicellulose ( $x$ ) & 21.40 & 0.99 & 7.97 & 1.99 & 22.83 & 0.51 \\
\hline (\%) Cellulose (a) & 43.37 & 2.91 & 35.21 & 3.33 & 43.58 & 2.23 \\
\hline
\end{tabular}

$\left({ }^{*}\right)=$ Immediate Chemical Composition

$\left({ }^{* *}\right)=$ Elementary Chemical Composition

$(a)=$ Chemical Composition of the Fibres 
Table 3 - BET results of the studied adsorbent

\begin{tabular}{lc}
\hline \multicolumn{1}{c}{ Parameters } & Pure ash \\
\hline Specific area $\left(\mathrm{g} \cdot \mathrm{m}^{2}\right)$ & 89 \\
Pore diameter $(\mathrm{A})$ & 45 \\
Total pore volume $\left(\mathrm{g} \cdot \mathrm{cm}^{3}\right)$ & 0,08 \\
Pore characteristic (IUPAC) & Mesoporous \\
Isotherm & Type IV \\
pH & 8,43 \\
Moisture & $3,83 \%$ \\
Loss of ignition & $91,93 \%$ \\
BJH (pore diameter range $\mathrm{nm})$ & $2,16-57,28$ \\
\hline
\end{tabular}

value is related to the amount of unburned carbon, the adsorption process

\subsection{Analysis of the main components in the characterization of the three biomasses}

From the results of the physicochemical analysis of the biomass types in study (SCB, PS and BGS), a matrix containing 9 rows and 15 columns was created, making up a total of 135 values. Figure 02 represents the graph containing the scores for the three biomass types on principal component 1 (PC1) in relation to principal component 2 (PC2), with $89.72 \%$ of the characterisation being made, while Figure 03 exhibits the weights in which it is possible to observe the correlation between the properties of PC1 and PC2.

In the PC1, Figure 2, the samples SCB1, SCB2 and SCB3 presented higher value because they contain high (\%) $\mathrm{O}$, (\%) ash and (\%) fixed carbon. As for fixed carbon, it means that the burning of this biomass for the production of the fuel gas will be more time consuming, requiring a greater amount of absorbed energy; ashes can cause a decrease in calorific value [27; 28]. As for oxygen, the result of the elemental analysis, its presence for the production of the combustible gas in a thermochemical process, such as gasification, will require less oxygen for the process, being less polluting, but consequently the amount of energy to be released will be reduced, thus decreasing the upper calorific value. It is the amount of oxygen in the reaction that will direct whether the burning is complete or not [29].

The samples PS1, PS2 and PS3 are characterized in PC1 (to the right) and in PC2 (above) of Figure 02, values higher in the calorific value, lower calorific value, (\%) volatile, (\%) C, (\%) N, (\%) lignin, (\%) H and (\%) S. The results of HCV and LCV demonstrate that this biomass has a good heat generation and probably a good yield for the thermochemical process, because the higher the heat power, which is the amount of energy released during heat transfer, the better it will be the efficiency of the process $[29 ; 30 ; 31]$. The percentages of $\mathrm{C}, \mathrm{N}, \mathrm{H}$ and $\mathrm{S}$, results of the elemental analysis indicate that possibly when this biomass is burned for the production of combustible gas in thermochemical processes, it will be possible to react and to produce several compounds favorable or not to its production, as for example the $\mathrm{H}_{2} \mathrm{~S}$, which is an undesirable contaminant [32; 33; 17]. As for lignin, because its calorific value is higher in comparison to cellulose and hemicellulose, to break this bond will require more energy absorbed for the solid-gas conversion process [34].

The samples BGS1, BGS2 and BGS3 stand out in PC1 (right) and PC2 (low) in Figure 02, the HCV, LCV and volatile parameters were highlighted, these values facilitate this biomass to have a good heat generation and a good performance of the thermochemical process, because the volatiles, the greater its percentage, the easier the burning and the more fuel gas generation [34].

The percentages of $\mathrm{N}, \mathrm{C}$ and $\mathrm{H}$ in the gas production process, probably several reactions will occur which will produce favorable compounds or not, for example, the $\mathrm{H} / \mathrm{C}$ and $\mathrm{O} / \mathrm{C}$ ratios their higher ratio means that the energetic value of the gas is reduced. The $\mathrm{H} / \mathrm{C}$ ratio of a biomass can originate from unsaturated structures, mainly aromatic rings characteristic of lignin, and the $\mathrm{O} / \mathrm{C}$ ratio may originate from the presence of oxygenated

Figure 02 - Graph containing the scores of the respective biomass types (SCB), (PS) and (BGS) on the first and second principal components (PC1 and PC2)

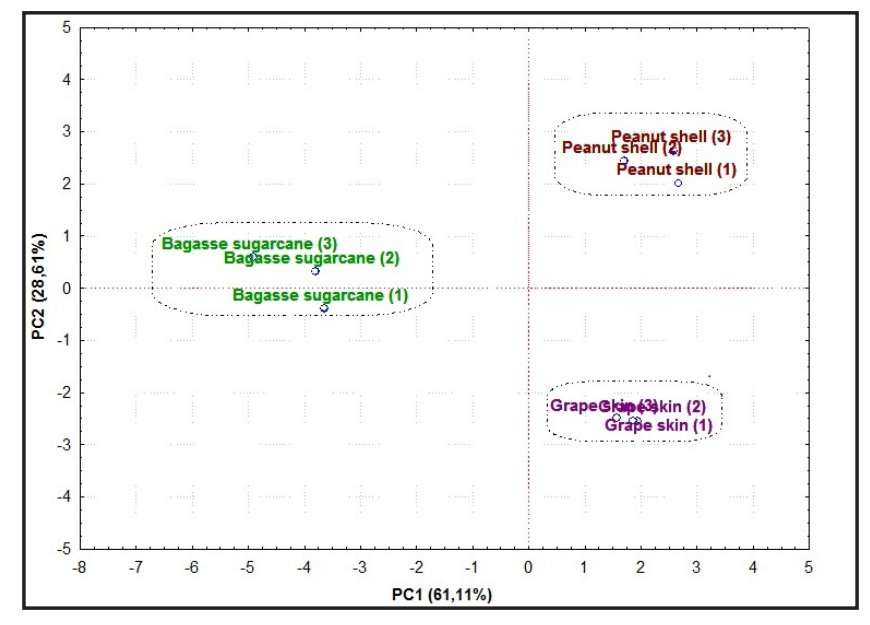


Figure 03 - Graph with weights of the first and second principal component (PC1 and PC2) in terms of the physicochemical properties of the biomass types in study

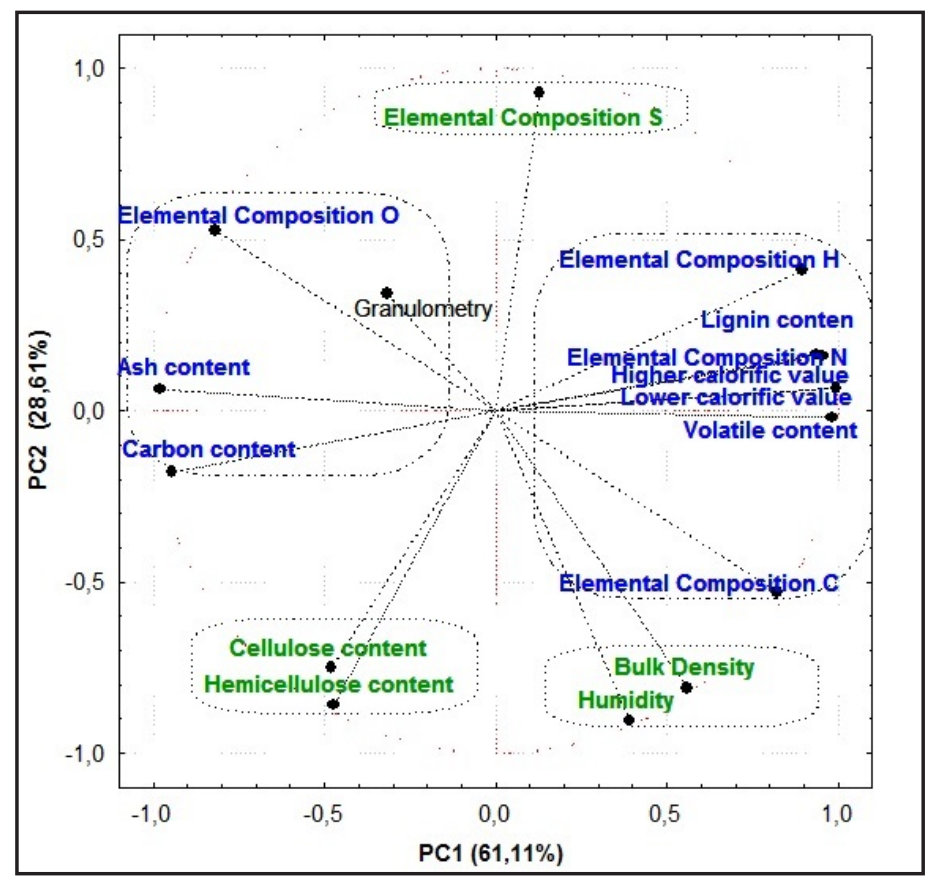

groups, mainly polysaccharides [35]. The high moisture content for any thermochemical process is undesirable because it decreases its efficiency [5]. The bulk density of a biomass is strongly related to moisture, because the higher the moisture, the lower the energy density, and this increases the transport costs of the biomass, affecting its logistics. Therefore, a suitable biomass for the solid-gas conversion process must have low moisture content and high density value Bocci et al. [6]. However, the composition of the cellulose, hemicellulose and lignin, all three, influence the choice of the solid-gas conversion process, however, the cellulose-lignin ratio to convert efficiently to gas, requires thermochemical means, since the lignin content is strongly connected to its calorific value [29].

\subsection{Adsorption coupled gasification step (fixed bed column)}

In the gasification step coupled to the adsorption column two objectives of this work were verified, the production of $\mathrm{H}_{2} \mathrm{~S}$ gas from biomass and the adsorbent capacity of ash from sugarcane bagasse. The gas produced from the gasification was collected after the gasifier and after the adsorption column and analyzed on the gas chromatograph, the results are shown in Table 04.

The generation of the $\mathrm{H}_{2} \mathrm{~S}$ gas was produced from gasification of the biomass that occurred due to the gas-solid thermochemical process, from the oxidation-reduction reactions in the fixed carbon molecules in which the sulfur is chemically bound, as evidenced by elemental analysis, as described by Virmond [36], which explains the following: the carbon, hydrogen and sulfur contents contribute positively to both HCV and LCV, since $\mathrm{C}, \mathrm{H}$ and $\mathrm{S}$ are oxidized during combustion by exothermic reactions forming the
Table 04 - Gasification step data coupled to adsorption

\begin{tabular}{c|c|c|c}
\hline Data & BGS & SCB & PS \\
\hline ADSORPTION COLUMN (Adsorbent - pure \\
ash) \\
\hline $\begin{array}{c}\text { Mass of adsorbent fixed } \\
\text { bed (g) }\end{array}$ & 3,3892 & 3,4165 & 3,3970 \\
$\begin{array}{c}\text { Fixed bed height of } \\
\text { adsorvente }(\mathrm{cm})\end{array}$ & 2,0 & 2,0 & 2,0 \\
\hline
\end{tabular}

GASIFICATION

Mass of biomass used (g) $\quad 8,3981 \quad 8,2151 \quad 8,0937$

CONCENTRATION OF $\mathrm{H}_{2} \mathrm{~S} \mathrm{em} \mathrm{mg.L^{-1 }}$ of biomass (GASIFIER OUTPUT)

\begin{tabular}{|c|c|c|c|}
\hline $\mathrm{H}_{2} \mathrm{~S}$ & 4,475 & 12,448 & 14,433 \\
\hline $\mathrm{H}_{2} \mathrm{~S}$ & 3,532 & 12,456 & 19,961 \\
\hline $\mathrm{H}_{2} \mathrm{~S}$ & 3,973 & 13,857 & 16,551 \\
\hline \multicolumn{4}{|c|}{$\begin{array}{l}\text { CONCENTRATION OF } \mathrm{H}_{2} \mathrm{~S} \text { em } \mathrm{mg.L}^{-1} \text { of biomass (AF } \\
\text { TER THE ADSORPTION COLUMN) }\end{array}$} \\
\hline $\mathrm{H}_{2} \mathrm{~S}$ & ND & ND & ND \\
\hline
\end{tabular}

ND: Not detected

gases $\mathrm{CO}_{2}, \mathrm{H}_{2} \mathrm{O}, \mathrm{H}_{2} \mathrm{~S}$ and $\mathrm{SO}_{2}$.

\subsection{Thermal analysis}

According to Figures 04,05 and 06 of the studied biomass the thermal analyzes were based on techniques that a physical property of a substance (and / or its products) is measured as a function of time or temperature while the 
Figure 4 - Thermal analysis of biomass peanut shell

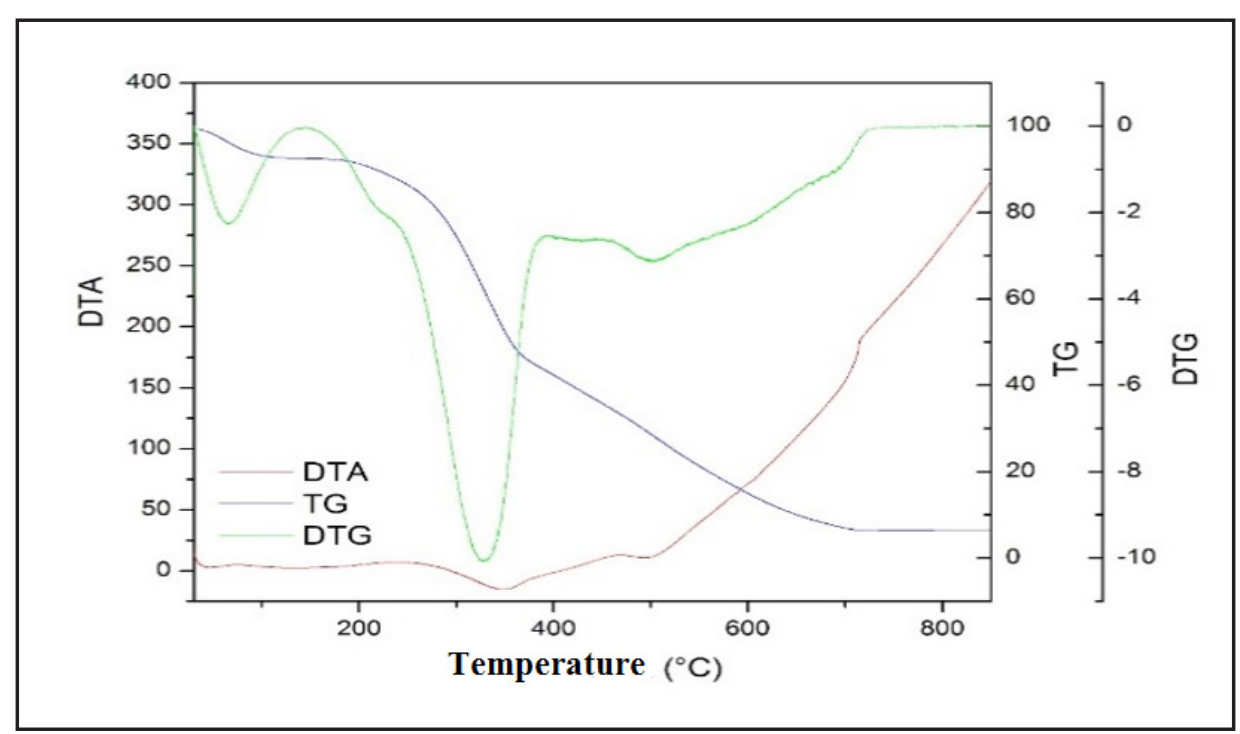

Figure 5 - Thermal analysis of sugarcane bagasse biomass

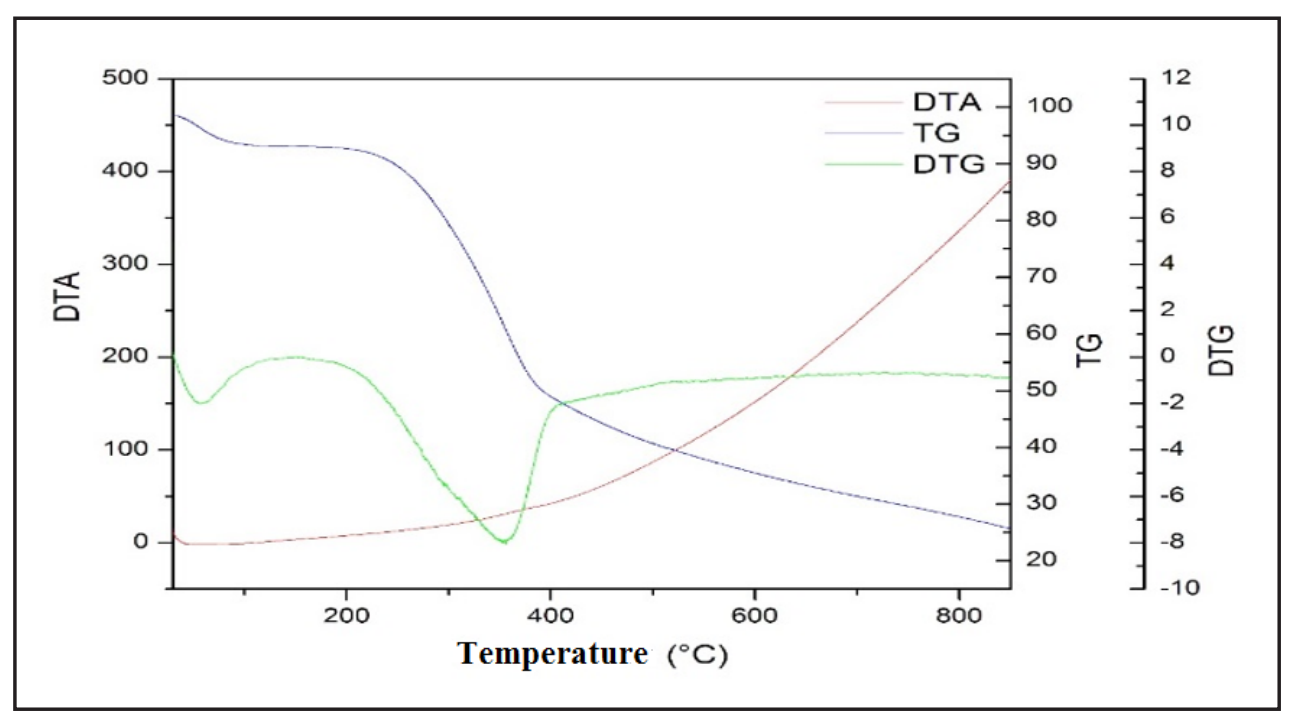

Figure 6 - Thermal analysis of the biomass black grapes skin

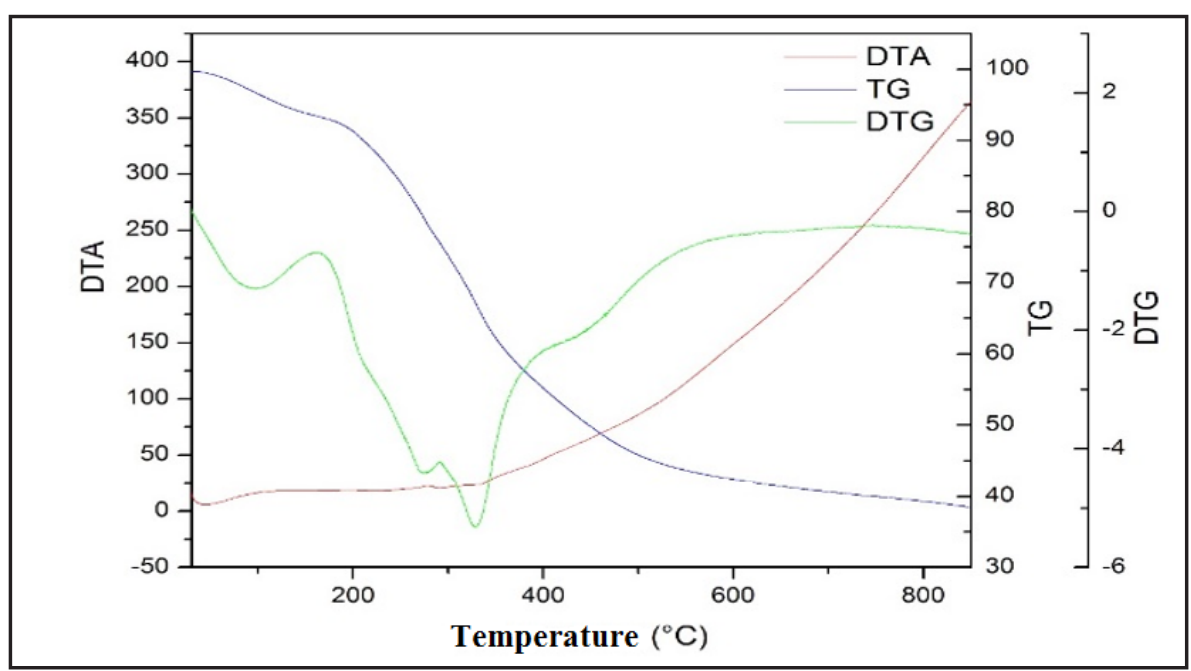


sample is submitted to controlled temperature program.

For the three biomasses studied and according to the thermogravimetric (TG) analysis, three zones of mass loss can be observed: the first, up to $200^{\circ} \mathrm{C}$ is due to the presence of different compounds (cellulose, hemicellulose and lignin), while the second $\left(200-350^{\circ} \mathrm{C}\right)$ and the third $\left(350-500{ }^{\circ} \mathrm{C}\right)$ are due to the conversion process. According to the explanation of Camponero and Tenório [37], for the behavior of the TG curves for the studied biomass they present a behavior of multiple stages of decomposition.

Due to the complexity of the studied lignocellulosic materials (mixture of cellulose, hemicellulose and lignin) one can still consider each fraction as a mixture of biopolymers. The analytical strategy is based on the fact that the three polymer families that mainly make up the biomass have different rates of decomposition temperatures. Hemicellulose is less resistant to thermal degradation, followed by cellulose and lignin. Hemicellulose and cellulose begin decomposing in the temperature range below $330{ }^{\circ} \mathrm{C}$, depending on the nature of the heteropolymers present in the biomass and the experimental conditions. However, lignin begins to decompose at temperatures above $300{ }^{\circ} \mathrm{C}$, as it needs more energy to gasify, according to Seye et al. [38].

In relation to the analysis of Derived Thermogravimetry (DTG) for the three biomasses studied, it has been demonstrated that endothermic events occurred. In relation to peanut, the race happened at a specific temperature, for the bagasse and grape the race happened in a temperature range decomposition). According to Ionashiro and Giolito [39], for the behavior of the DTG curves for the studied biomass, the indication of weight losses of the samples should be indicated through downward shifts in the curves.

Differential thermal analysis (DTA) refers to the temperature gradient that involves heating the sample and the reference material in such a way that the sample increases linearly with time [39].

\section{Conclusion}

Based on the results presented, all biomass types studied presented very similar values of both HCV and LCV, demonstrating a considerable amount of heat generation, with a significant efficiency of the thermochemical process. This is due to the fact that the higher the HCV, i.e. the heat released during heat transfer, the better the efficiency of the process; with the biomass type peanut shell obtaining a better overall result. It is also possible to observe the presence of $\mathrm{N}, \mathrm{C}, \mathrm{H}, \mathrm{S}$ and $\mathrm{O}$, that will possibly react in the gasification process, producing various compounds favourable or not to the production of synthesis gas;

As pure ash, being an industrial waste and having low cost also presented an adsorbent to adsorb $\mathrm{H}_{2} \mathrm{~S}$;

The generation of $\mathrm{H}_{2} \mathrm{~S}$ gas was produced from gasification of the biomass that occurred due to the gas-solid thermochemical process, from the oxidation-reduction reactions on the fixed carbon molecules in which the sulfur is chemically bound, as evidenced by elemental analysis;

In relation to the generated amounts of $\mathrm{H}_{2} \mathrm{~S}$ of each biomass, considered a contaminant, the need to be removed for fuel production;

The thermal analysis was fundamental for the fact that the three families of polymers that mainly make up the biomass, have different rates of decomposition temperatures;

Advantages of fixed bed application: small space; Simple operation; ability to accommodate variations in feed concentration and easy scaling from laboratory to industrial scale.

\section{References}

Bowe, M.J.; Peat, R.; West, D.J.; Hawker P. Gas-to-liquid technology. Google Patents, 2015.

Bao, B.; El-Halwagi, M.M.; Elbashir, N.O. Simulation, integration, and economic analysis of gas-to-liquid processes. Fuel Process Technology, 2010.

Aguiar, E.F.S. Biocombustíveis e a Refinaria do Futuro. Escola de Química/UFRJ e CENPES/PETROBRAS, 2011.

Bizzo, W.A.; Lenço, P.C.; Carvalho, D.J.; Veiga, J.R.S.The generation of residual biomass during the production of bio-ethanol from sugar cane, its characterization and its use in energy production. Faculty of Mechanical Engineering, University of Campinas - UNICAMP, 13083-970 Campinas, SP, Brazil, 2014.

Messina, L.I.G; Bonelli, P.R.; Cukierman, A.L. Copyrolysis of peanut shells and cassava starch mixtures: Effect of the components proportion. Facultad de Ciencias Exactas y Naturales, Universidad de Buenos Aires, Ciudad Universitaria, Intendente Güiraldes 2620, C1428BGA Buenos Aires, Argentina, 2015.

Bocci, E.; Sisini, M.; Moneti, M.; Vecchione, L.; Di Carlo, A.; Villarini, M. State of art of small scale biomass gasification power systems: a review of the different typologies. Engineering Faculty, Energy Department, Marconi University, Rome 00143, Italy, 2014.

Mckendry, P. Energy production from biomass (part 1): overview of biomass. Bioresource Technology, v.83, p.37-46, 2002a.

Saidur, R.; Abdelaziz, E.A.; Demirbas, A.; Hossain, M.S.; Mekhilef, S. A review on biomass as a fuel for boilers. Renewable and Sustainable Energy Reviews, v.15, p.22622289, 2011.

Andrade, R.V. Estado da Arte da Gaseificação de Biomassa para Geração de Eletricidade e Produção de Combustíveis. Universidade Federal de Itajubá, Brasil, 2010. 
Higman, C.; Burgt, M. Gasification. United Kingdom: Elsevier, 2 ed., 435p, 2008.

Ronkkonen, H.; Simell, P.; Niemela, M.; Krause, O. Precious metal catalysts in the clean-up of biomass gasification gas part 2: Performance and sulfur tolerance of rhodium based catalysts. Aalto University, School of Science and Technology, Department of Biotechnology and Chemical Technology. Technical Research Centre of Finland, Journal Elsevier, Finland, 2011.

Nascimento, R.F.; Lima, A.C.A.; Vidal, C.B.; Melo, D.Q.; Raulino, G.S.C. Adsorção - Aspectos Teóricos e Aplicações Ambientais. Editora UFC, Fortaleza, Brasil, 2014a.

Doudart de la Grée, G.C.H.; Florea, M.V.A.; Keulen, A.; Brouwers, H.J.H. Contaminated biomass fly ashes Characterization and Treatment optimization for reuse as building materials. Department of the Built Environment, Unit Building Physics and Services, Eindhoven University of Thechnology, The Netherlands, 2016.

Oliveira, D.L.A. Caracterização da cinza de bagaço de cana-de-açúcar e aplicação no solo. Tese de Doutorado, Universidade Estadual de1 Paulista, Campos de Jaboticabal, Brasil, 2015.

Vassilev, S.V.; Baxter, D.; Andersen, L.K. Vassileva, C.G. An overview of the composition and application of biomass ash. Part 2. Potential utilization technological and ecological advantages and challenges. Institute for Energy and Transport, Joint Research Centre, European Commission, Netherlands, 2013b.

Hachimi, A.; Vilcocq, L.; Coursn, C. Kiennemann, A. Study of olivine supported copper sorbents performances in the desulfurization process in link with biomass gasification. Institut de Chimie et Procédés pour 'Energie, l'Environnement et la Santé (ICPEES), France, 2014.

Chytil, S.; Lind, A.; Vanhaecke, E.; Blekkan, E.A. Preparation and Characterization of MnxOy - Al2O3 Sorbents for H2S removal from Biomass Gasification Gas. Norway, 2012.

Barros Neto, B.; Scarminio, I.; Bruns, R. Como fazer experimentos. 4 ed., 414p, São Paulo: Bookman, Brasil, 2010 .

Lora, E. E.; Gómez, E.O.; Cortez, L.A. Biomassa para energia. 1 ed., 728p, São Paulo: Editora da Unicamp, Brasil, 2009.

Van Söest, R.; Robertson, J. Analysis of forages and fibrous foods: a laboratory manual. Ithaca, NY: Cornell University, 1985.

James B, C. Chapter 2 - Measuring the Physisorption Isotherm. In: (Ed.). Surface Area and Porosity
Determinations by Physisorption. Amsterdam: Elsevier Science, p.29-53. ISBN 978-0-444-51964-1, 2006.

Días, J. M. R. Caracterização e Avaliação das Cinzas do Bagaço de Cana-de-Açúcar como Adsorvente na Remoção dos Íons Cd(II), Ni(II) e Zn(II) de Soluções Aquosas. Tese de Doutorado, UFPE, Brasil, 2013.

Izidoro, J.C.; Fungaro, D.A.; Santos, F.S.; Wang, S. Characteristics of Brazilian coal fly ashes and their synthesized zeolites. Chemical and Environmental Technology Center, Nuclear and Energy Research Institute, São Paulo, Brazil and Department of Chemical Engineering, Curtin University, Australia, 2012.

TC Wi. Chemical Analyses - Determination of loss on ignition in sediment, sludge, soil, and waste. Élément introductif - Élément central - Élément complémentaire. Standard European - 2003.

Bastos, D.M. Métodos Cromatográficos, www.fsp. br/ dmbastos/cromatografia.ppt. São Paulo, Brasil, 2005.

Pécora, A.A.B.; Ávila, I.; Lira, C.S.; Cruz, G.; Crnkovic, P.M. Prediction of the Combustion Process in Fluidized bed on physical-chemical properties of biomass particles and their hydrodynamics behaviors. University of Campinas, Scool of Mechanical Engineering, S.P., Brazil, 2014.

Duman, G.; Uddin, Md. A.; Yanik, J. The effect of char properties on gasification reactivity. Faculty of Science, Department of Chemistry, Izmir Institute of Technology, Izmir, Turkey, 2014.

Senglei, Du.; Haiping, Y.; Kezhen, Q.; Xianhua, W.; Hanping, C. Fusion and transformation properties of the inorganic components in biomass ash. State Key Laboratory of Coal Combustion (Huazhong University of Science and Technology), Hubei Province, China, 2014.

Geraldo, B.C.A. Gaseificação da Casca e da Torta da Mamona para Produção de Gás Combustível. Dissertação de Mestrado, Recife-PE, Brasil, 2013.

Duan, F.; Chyang, C.S.; Wang, Y.J.; Tso, J. Effect of secondary gas injection on the peanut shell combustion and its pollutant emissions in a vortexing fluidized bed combustor. School of Energy and Environment, Anhui University of Technology, Maanshan, Anhui Province, China, 2014.

Tsiakmakis, S.; Mertzis, D.; Dimaratos, A.; Toumasatos, Z.; Samaras, Z. Experimental study of combustion in a spark ignition engine operating with producer gas from various biomass feedstocks. Laboratory of Applied Thermodynamics, Department of Mechanical Engineering, 
Aristotle University of Thessaloniki, Thessaloniki, Greece, 2014.

Toscano, G.; Riva, G.; Duca, D.; Pedretti, E.F.;Corinaldesi, F.; Rossini, G. Analysis of the characteristics of the residues of the wine production chain finalized to their industrial and energy recovery. Dipartimento di Scienze Agrarie, Alimentari e Ambientali dell'Universita Politecnica delle Marche, Via Brecce Bianche, Monte Dago, Italy, 2013.

Kuprianov, V.I.; Arromdee, P. Combustion of peanut and tamarind shells in a conical fluidized-bed combustor: A comparative study. School of Manufacturing Systems and Mechanical Engineering, Sirindhorn International Institute of Technology, Thammasat University, Thailand, 2013.

Santos, H.; Peres, S. Aproveitamento dos resíduos de biomassa da construção civil (RCC) para geração de combustíveis sólidos (pellets) e gasosos. Prêmio Odebrecht para desenvolvimento sustentável, 20p, Brasil, 2012.

Gomes, B.L.; Martelli, F.H.; Silva, W.T.L. Caracterização físico-quimica e morfológica de Biomassa Capim-elefante, Capim-mombaça.bracharia, Sorgo-embrapa e Bagaço de cana-de-açúcar. III Symposium on Agricultural and Agroindustrial Waste Management. São Pedro-SP, Brasil, 2013.

Virmond, E. Aproveitamento do lodo de tratamento primário de efluentes de um frigorífico como fonte de energia. Dissertação de mestrado, UFSC - Florianópolis/ SC, Brasil, 2007.

Camponero, J.; Tenório, J.A.S. Técnicas de Análises Químicas. Estudo Dirigido PMI 2201 - Análises Térmicas, Brasil, 2001.

Seye, O.; Cortez, L.A.B.; Gómez, E.O. Estudo Cinético da Biomassa a partir de resultados Termogravimétricos. Área Interdisciplinar de Planejamento de Sistemas Energéticos. Faculdade Mecânica, Universidade Estadual de Campinas, Campinas-SP-Brasil, 2003.

Ionashiro, M.; Giolito, I. Nomenclatura, Padrões e Apresentação dos resultados em Análise Térmica. Departamento de Química Fundamental, Instituto de Química da Universidade de São Paulo, Brasil, 2008. 